\title{
PERgulatan pemikIRAN KIAI NAHDLATUL ULAMA DENGAN KAUM MODERNIS ISLAM DI JAWA BARAT (1930-1937)
}

\section{THE THOUGHT OF STRUGGLE OF NADHLATUL ULAMA KYAI WITH ISLAM MODERNIST IN WEST JAVA (1930-1937)}

\author{
Agung Purnama, Nina Herlina Lubis, Widyonugrahanto \\ Mahasiswa Program Magister Ilmu Sejarah Universitas Padjadjaran, Jl. Raya Bandung-Sumedang \\ Km. 21 Jatinangor \\ e-mail: agoeng.poernam@gmail.com
}

\begin{abstract}
Abstrak
Nahdlatul Ulama adalah organisasi bercorak Islam tradisional yang dibentuk pada tahun 1926 di Surabaya Jawa Timur. Selanjutnnya NU menyebar luas ke wilayah lain di Pulau Jawa. Sementara itu, Jawa Barat adalah sebuah wilayah yang pada dekade 1920-1930-an merupakan lahan subur tempat tumbuh dan berkembangnya organisasi Islam bercorak modernis Di sana banyak bermunculan tokoh-tokoh pembaharu yang "agresif" dalam berdakwah menentang amaliah-amaliah keagamaan masyarakat Islam tradisional. Oleh karena itu, ketika NU masuk ke Jawa Barat, sangat mungkin akan disertai "gesekan" dengan organisasi Islam modernis setempat. Dalam mengkaji permasalahan ini penulis menggunakan metode sejarah yang terdiri dari empat tahap; heuristik, kritik, interpretasi, dan historiografi. Hasil penelitian menunjukkan bahwa di Jawa Barat kerap terjadi pergulatan pemikiran dalam masalah sumber penetapan hukum agama. Bagi para kiai NU taqlid kepada hasil ijma' para ulama mazhab hukumnya boleh, tetapi bagi kaum modernis perilaku bermazhab adalah haram. Umat Islam wajib kembali kepada Al-Qur'an dan Hadis sebagai sumber hukum utama. Selain itu, yang menjadi topik perdebatan adalah permasalahan bid'ah atau sunnah-nya tradisi-tradisi keagamaan yang berkembang di masyarakat sejak lama.
\end{abstract}

Kata kunci: kiai NU, kaum modernis, pegulatan pemikiran, perdebatan, Jawa Barat.

\section{Abstract}

Nahdlatul Ulama is a traditional Islamic organization formed in 1926 in Surabaya East Java. NU then spread widely to other regions on the island of Java. In the 1920 to the 1930s, West Java is a region which was an appropriate land for the growth and development of modernist Islamic organizations. There were many emerging reformers who are "aggressive" in preaching against the religious amaliah of traditional Islamic society. Therefore, it is possible that the development of $\mathrm{NU}$ in West Java will be accompanied by "friction" with the local modernist Islamic organization. In studying this problem the author uses a historical method consisting of four stages; Heuristics, criticism, interpretation, and historiography. The results show that in West Java there is often a struggle of thought between the NU kyai with the modernists in the issue of the source of the determination of religious law. For the NU kyais, taqlid to the result of ijma 'the scholars of the legal school may be, but for the modernists the behavior of the schools of thought is haram and the Muslims are obliged to return to the Qur'an and Hadith as the main source of law. In addition, the topic of the debate between NU kyais and modernists is the heresy or sunnah of religious traditions that have developed in society for a long time. The struggle of thought between the NU kyai and the modernist was raised several times in the forums shown to the public.

Keywords: kyai NU, modernist, thought struggle, debate, West Java. 


\section{A. PEndahuluan}

Jam'iyah Dinniyah Islamiyah Nahdlatul Ulamal merupakan sebuah organisasi massa yang dibentuk oleh para kiai pemimpin pesantren tradisional. Nahdlatul Ulama (berikutnya disingkat NU) didirikan di Surabaya pada 16 Rajab $1344 \mathrm{H}$ bertepatan dengan 31 Januari 1926 M (Statuten Perkoempoelan Nahdlatoel Oelama. Th. 1926. Fatsal 1. Hlm. 2). Bersama Muhammadiyah (berdiri 18 November 1912) dan Persatuan Islam (berdiri 12 September 1923), NU adalah organisasi keagamaan yang masih eksis sampai sekarang. Wadah aspirasi masyarakat Islam tradisional ini memiliki jaringan yang sangat luas dan tersebar di seluruh wilayah Indonesia. Bahkan, baik jamiah maupun jamaahnya, NU diyakini sebagai organisasi terbesar di Indonesia. Menurut Nugroho (2010: 19) jumlah kaum Nahdliyin diperkirakan mencapai lebih dari 40 juta orang dari beragam profesi. Sementara itu pihak PBNU sendiri memperkirakan jumlah anggota berikut simpatisannya, adalah mencapai 90 juta orang.

Tujuan dibentuknya NU adalah untuk mengemban dan memegang teguh ajaran salah satu dari empat mazhab demi kemaslahatan agama Islam (Statuten Perkoempoelan Nahdlatoel Oelama Fatsal 2, Th. 1926: 2). Hal itu perlu dilakukan, mengingat pada abad ke-19 dunia Islam dihadapkan pada gerakan pembaharuan

${ }^{1}$ Nahdlatul Ulama memiliki arti "kebangkitan para ulama". Organisasi ini dibentuk oleh sekumpulan ulama yang terdiri dari $\mathrm{KH}$. Hasyim Asy'ari, KH. Bisri Syansuri dari Denayar Jombang, KH. Asnawi dari Kudus, KH. Nawawi dari Pasuruan, KH. Ridwan dari Semarang, KH. Maksum dari Lasem, KH. Nahrawi dari Malang, H. Doro Muntaha dari Bangkalan Madura, KH. Abdul Hamid Faqih dari Gresik, KH. Ridwan Abdullah, KH. Mas Alwi, KH. Abdullah Ubaid dari Surabaya, Syaikh Ahmad Ghonaim dari Mesir, dan KH. Abdul Halim dari Leuwimunding (Zuhri, 1979: 609; Anam, 2010: 389). yang mencoba "memberangus" praktikpraktik keagamaan kalangan Islam tradisional. Dalam pandangan kaum modernis, kemandegan yang tengah melanda dunia Islam disebabkan oleh perilaku umatnya yang banyak melakukan "penyimpangan" syariat agama. Perilaku sufistik dan berbagai amaliah bid'ah dan tasyrik bentuk penyimpangan syariat yang daripadanya memunculkan sikap stagnasi dalam berfikir (jumud). Belum lagi sikap taqlid terhadap fatwa ulama turuntemurun, juga dianggap sebagai biang kemunduran umat Islam. Para tokoh pembaharu mengklaim bahwa potensi Islam harus digali melalui semangat rasionalisme. Islam harus dipacu ke arah kemajuan agar dapat menghadapi perubahan zaman akibat modernisasi, dengan berlandaskan sumber-sumber yang berwibawa, yaitu Al-Qur'an dan Hadis. Islam harus kembali kepada Islam sejati, Islam sebagaimana dipraktikkan pada zaman klasik (Nasution, 1974: 99).

Dalam menyikapi isu-isu pembaharuan yang muncul dari Timur Tengah tersebut, tokoh-tokoh Islam di Hindia Belanda terdikotomikan ke dalam dua kelompok besar. Kelompok pertama merupakan pendukung pembaharuan dan pemurnian Islam. Mereka sering diistilahkan dengan beberapa sebutan; kaum modernis, pembaharu, atau reformis. Kelompok kedua merupakan kalangan yang antipati terhadap gerakan pembaharuan. Mereka dimotori oleh para kiai dan ulama konservatif yang bermaksud melestarikan tradisi keagamaan. Di antara kedua kelompok tersebut, seringkali terjadi pertentangan dan perdebatan akibat adanya khilafiyah dalam agama. Bahkan justifikasi bid'ah, kafir, sesat, dan musyrik kerap muncul di tengah-tengah perdebatan (Anam, 2010: 48).

Sementara itu, Jawa Barat dalam kurun waktu 1920 sampai 1930-an merupakan sebuah wilayah yang menjadi tempat tumbuh suburnya berbagai organisasi Islam. Beragam organisasi 
keagamaan lahir di Jawa Barat baik yang eksistensinya memiliki jangkauan luas seperti Persis, Matla'ul Anwar dan AII, maupun yang terbatas di daerah tertentu seperti Pemufakatan Islam di Bandung, Wira'i dan PGN di Tasikmalaya, Jami'atul Muti'in dan Jami'atul Hasanah di Garut, Penolong Sekolah Agama (PSA) di Sukabumi, dan lain-lain (Iskandar, 2001: 164-189). Jumlah ini masih ditambah dengan organisasi keagamaan yang datang dari luar seperti Muhammadiyah dan AlIrsyad, serta organisasi Islam yang bersifat politis semacam Sarekat Islam. Organisasiorganisasi itu ada yang menawarkan ide pembaharuan ada pula yang menawarkan gagasan pelestarian tradisi keagamaan di masyarakat. Oleh karena itu, Nahdlatul Ulama sebagai organisasi "pendatang" di Jawa Barat, kehadirannya sudah barang tentu akan terseret lingkaran konflik bersama organisasi-organisasi yang ada. Perbedaan paham keagamaan, orientasi gerakan dan kultur organisasi sangat memungkinkan NU "diserang" oleh organisasi Islam lain yang berseberangan pemikiran. Berkaitan dengan itu, menarik untuk dikaji bagaimana perdebatanperdebatan yang terjadi antara kalangan tradisional yang diwakili oleh para kiai NU, dengan kaum modernis di Jawa Barat.

Dalam mengkaji permasalahan ini, beberapa literatur penulis jadikan sebagai tinjauan pustaka, di antaranya adalah buku karya Muhammad Iskandar yang berjudul Pergulatan Pemikiran Kiai dan Ulama di Jawa Barat, 1900-1950. Sesuai judulnya, buku ini menjelaskan beberapa bentuk pemikiran ala kiai di Jawa Barat khususnya di wilayah Priangan, sehingga dari pemikiran tersebut muncul pertentangan di antara kiai tradisional (ajengan) dengan golongan modernis. Buku ini cakupan pembahasannya hanya di wilayah Priangan, dengan Sukabumi dan Cianjur sebagai penekanan. Studi kasus dari pembahasan buku ini adalah KH. Ahmad Sanusi di Sukabumi atau yang dikenal dengan sebutan ajengan Gunung Puyuh Sukabumi. Maka dari itu, perbedaan antara buku ini dengan penelitian yang dilakukan oleh penulis adalah; Muhammad Iskandar membahas pergulatan pemikiran antara KH. Ahmad Sanusi (bersama AII-nya) dengan kaum modernis, sedangkan penulis membahas pergulatan pemikiran antara kaum modernis dengan para kiai NU.

Ruang lingkup temporal yang akan dikaji dalam penelitian ini adalah tahun 1930-1937. NU telah berdiri tahun 1926, namun pergulatan pemikiran antara para kiai NU dengan kaum modernis mulai intens pada memasuki tahun 1930-an. Adapun tahun 1937 dijadikan sebagai batas akhir kajian adalah karena pada tahun tersebut pergulatan pemikiran antara kaum modernis dengan pihak tradisionalis telah mereda seiring ditemukannya konsensus bersama bagi umat Islam, dalam wujud MIAI. Unsur spasial yang akan dikaji dalam penelitian ini adalah beberapa wilayah di Jawa Barat, seperti di daerah Keresidenan Cirebon, Keresidenan Priangan, dan Keresidenan Batavia, di mana perdebatan-perdebatan terbuka sering terjadi pada wilayah-wilayah tersebut.

\section{B. METODE PENELITIAN}

Metode yang akan digunakan dalam penelitian ini adalah metode sejarah. Metode sejarah terdiri atas empat tahap, yaitu heuristik, kritik, interpretasi, dan historiografi.

Tahap pertama yang akan dilakukan dalam metode sejarah adalah heuristik. Heuristik merupakan kegiatan mencari dan menemukan serta menghimpun berbagai informasi dari sumber sejarah. Sumber sejarah menurut Sjamsuddin (2007: 75) adalah segala sesuatu yang langsung atau tidak langsung menceritakan kepada kita tentang sesuatu kenyataan atau kegiatan manusia pada masa lalu (past actualy). Sumber sejarah merupakan bahan-bahan mentah (raw materials) sejarah yang mencakup segala macam evidensi (bukti) yang ditingggalkan oleh manusia, sebagai penunjuk segala aktivitas mereka pada masa lalu. Ismaun 
(2005: 35) menyatakan bahwa sumber sejarah adalah rekaman sejarah dari bekasbekas peninggalan masa lampau guna memperoleh pengetahuan sejarah. Sumber sejarah juga diidentikkan dengan jejakjejak (traces) yang jejak-jejak masa lampau itu dikenal dengan sebutan sumber sejarah atau historical source (Herlina, 2015: 7). Kegitan heuristik ini akan menunjukkan keterampilan seseorang dalam melacak sumber-sumber yang terkait (Renier, 1997: 113).

Tahapan kedua dalam metode sejarah adalah kritik. Berkenaan dengan langkah kritik, para ahli sepakat bahwa kritik dibagi menjadi dua bagian, yaitu kritik eksternal dan kritik internal. Pertama kritik eksternal, yaitu dilakukan untuk menilai otentisitas dan integritas sumber sejarah. Dalam kritik eksternal, dipersoalkan bahan dan bentuk sumber, umur dan asal sumber, kapan dibuat (sudah lama atau belum lama sesudah peristiwa terjadi), dibuat oleh siapa, instansi apa, atau atas nama siapa, sumber itu asli atau salinan dan masih utuh seluruhnya atau sudah berubah (Ismaun, 2005: 50). Kedua, kritik internal, yaitu untuk mempertanyakan kredibilitas isi sumber. Dalam kritik internal, sumber dipersoalkan dari aspek isi, kemampuan, tanggung jawab dan moralnya pembuatnya dengan membandingkan isi sumber tersebut dengan kesaksian-kesaksian dari sumber lain (Ismaun, 2005: 50). Adapun kritik internal hanya dapat dilakukan terhadap penulisan yang ada dalam dokumendokumen atau pada inskripsi pada monumen, mata uang, medali atau stempel (Renier, 1997: 116).

Tahap ketiga dari metode sejarah disebut interpretasi. Ada lima jenis interpretasi, yaitu interpretasi verbal, interpretasi teknis, interpretasi logis, interpretasi psikologis, dan interpretasi faktual (Garraghan, 1957: 321-337). Dalam tahap interpretasi fakta-fakta sejarah dirangkai menjadi suatu rentetan tak terputus dari suatu peristiwa. Interpretasi seringkali dianggap sumber subjektivitas, karena dalam proses ini terkadang masuk pemikiran-pemikiran penulis atas suatu fakta sejarah. Dalam penulisan sejarah subjektifitas memang diakui, sekaligus harus dihindari. Oleh karena itu interpretasi merupakan sebuah tahapan yang cukup sulit karena penulis harus bersikap netral terhadap sumber yang ada. Penulis harus mengambil jarak dengan sumber agar tidak terlalu dekat dan menimbulkan bias.

Tahap terakhir dalam metode sejarah adalah penulisan yang disebut historiografi. Dalam tahap ini kemampuan menulis sangat dipertaruhkan Sebuah tulisan yang kreatif tentu membutuhkan kecerdasan dan imajinasi. Kecerdasan di sini artinya bersikap kritis pada setiap sumber, dengan disertai analisis yang tajam. Sementara imajinasi memiliki pengertian bahwa seorang penulis harus mampu membayangkan bagaimana sebuah peristiwa terjadi sehingga menghasilkan sebuah historiografi yang baik. Dalam tahap historiografi ini sejarawan tidak diizinkan untuk mengimajinasikan hal-hal yang tidak logis terjadi, ia hanya diizinkan menghayalkan hal-hal yang kiranya pasti terjadi dengan ketentuan-ketentuan yang sifatnya umum (Gottschalk, 2006: 40).

Untuk mendapatkan eksplanasi sejarah dari penelitian ini penulis menggunakan teori konflik dari Ralf Dahrendorf. Dalam teorinya, Dahrendorf mengemukakan bahwa masyarakat sebagai sistem sosial adalah terdiri atas kepentingan-kepentingan yang berbedabeda. Berdasarkan kepentingan yang berbeda tersebut, di dalamnya terdapat suatu usaha untuk menaklukkan komponen lainnya demi pemenuhan kepentingan yang sebesar-besarnya. Dahrendorf menyebutkan bahwa masyarakat yang dinamis memiliki potensi konflik dan integrasi. Masyarakat tidak akan ada tanpa adanya konsensus dan konflik yang menjadi prasyarat satu sama lain, di mana masyarakat tidak akan punya konflik kecuali ada konsensus sebelumnya (Ritzer dan Goodman, 2010: 153-154). 


\section{HASIL DAN BAHASAN \\ 1. Pergulatan Pemikiran NU dengan Organisasi Modernis di Jawa Barat}

Sejauh pengamatan penulis, organisasi Islam modernis yang paling sering menjadi lawan debat NU adalah Persis. Setidaknya begitu yang terdokumentasikan dalam majalah-majalah yang memuat hasil-hasil perdebatan di antara organisasi-organisasi Islam di Jawa Barat. Hal ini dikarenakan sifat Persis yang agresif dalam berdakwah, selalu menyerang siapa saja yang tidak sepemikiran dengan paham keagamaan Persis. Sehingga, Persis boleh dikatakan merupakan organisasi modernis yang paling terkenal dalam soal debatmendebat. Selain Persis, di wilayah Priangan yang sering menyerang pemahaman dan amaliah kaum tradisionalis adalah Majlis Ahli Sunnah Cilame (MASC) ${ }^{2}$.

Isu yang biasa diangkat dan disebarluaskan kepada umat Islam adalah kembali kepada Al-Qur'an dan Hadis Shahih, wajib berijtihad haram bertaqlid, haram bertaqlid kepada empat mazhab (Imam Hanafi, Imam Maliki, Imam syafi'i, dan Imam Hambali), serta masalah ritual keagamaan yang apabila tidak ada dari anjuran dari Rasul maka semua dipandang bid'ah tercela, para pelakunya akan masuk neraka. Hal-hal seperti itu sering dijadikan bahan untuk menyerang kalangan Islam tradisional dan kemudian mendapat reaksi yang keras dari para kiai tradisional. Jika di wilayah Priangan Barat Persis tercatat banyak berdebat dengan pihak AII yang dimotori oleh KH. Ahmad Sanusi ${ }^{3}$, maka di wilayah Cirebon dan

2 Tokoh-tokoh MASC pada mulanya merupakan ulama-ulama tradisional. Mereka kemudian tertarik dan berpindah haluan kepada gerakan pembaharuan karena keterlibatan mereka di SI atau di PSI, atau karena diakibatkan kalah berdebat dengan Persis (Iskandar, 2001: 170-171).

${ }^{3}$ Lihat Iskandar (2001: 232-255).
Priangan Timur Persis mendapat perlawanan yang kuat dari para kiai NU.

Pada 19 Juni 1932 di Ciledug Cirebon NU terlibat perdebatan dengan para kiai modernis dari Persis dan MASC. Perdebatan ini merupakan perdebatan secara terbuka pertama bagi masingmasing pihak. Majalah Tjahja Islam tahun 1932 memberitakan bahwa acara perdebatan ini diberi nama "Openbare Debat Vergadering Kiai Nahdlatoel Oelama Tjirebon Contra Kiai Modern". Dari pihak NU yang maju ke arena adalah KH. Abdul Khair, pengurus NU cabang Cirebon. Sedangkan dari kubu kiai modern diwakili KH. Muhammad Anwar Sanusi dari MASC. Acara perdebatan dilakukan dengan pendekatan formal. Ketua perdebatan yang memimpin acara adalah H. Agus Salim dari Partai Sarekat Islam Indonesia (PSII), yang dibantu dibantu oleh H. Alimoen, ketua PSII cabang Cirebon sebagai notulen. Sebelum acara dimulai, ketua sidang meminta supaya kedua belah pihak mengangkat Commisie Verslag yang akan mencatat setiap dalil dan hujjah peserta debat. Permintaan ini dipenuhi, NU mengangkat Mas Sastramihardja seorang Mantri Guru Ciledug yang menjadi anggota NU cabang Cirebon. Sementara dari pihak kiai modern diangkat Ahmad Hasan (pimpinan pusat Persis) yang dibantu oleh Soekantawidjaya dari MASC sebagai Commisie Verslag (Tjahaja Islam, No. 28, bulan Juni 1932: 8).

Debat yang dimulai bada zuhur ini dihadiri oleh ribuan umat Islam Indonesia dan ratusan orang Arab. Materi keagamaan yang akan diperdebatkan oleh kedua belah pihak adalah tentang talqin, tahlil dan sidkah bagi orang yang sudah meninggal. Dalam perdebatan itu, KH. Anwar Sanusi meminta kepada lawan debatnya untuk dapat memaparkan hadis yang sahih yang menganjurkan melakukan talqin, tahlil dan sidkah bagi orang yang sudah meninggal. Sebaliknya KH. Abdul Khair juga meminta kepada KH. Anwar Sanusi untuk memaparkan dalil yang melarang secara 
tegas bagi pelaksanaan tradisi-tradisi tersebut. Ia berpendapat bahwa tradisitradisi seperti itu adalah tradisi yang baik untuk dilaksanakan meskipun tidak pernah dilakukan oleh Rasulullah. Anggap saja merupakan sebuah kebaikan, kebaikan dengan cara mendoakan orang yang sudah meninggal. Sementara KH. Anwar Sanusi berpendapat bahwa tradisi-tradisi yang demikian itu merupakan sebuah bentuk penambahan atas syariat agama yang sudah ditetapkan. Bagi KH. Anwar Sanusi, berdasarkan ayat dalam surat Al-Maidah ayat 3 , Islam sudah sempurna tidak perlu ditambah atau dikurangi oleh tradisi yang dibuat oleh manusia (Tjahaja Islam, No. 28, bulan Juni 1932: 9-12).

Pada bulan Maret 1935 perdebatan terbuka antara NU dengan Persis terjadi di Tasikmalaya. Tablig akbar yang diselenggarakan oleh Persis di Cisalak berubah menjadi arena debat karena acara tersebut dihadiri oleh pengurus NU cabang Tasikmalaya. Acara tablig akbar tersebut dipimpin oleh H. Zamzam, $H$. Soekantawijaya sebagai notulen, sementara H. Romli, Ustad Abdurrahman dari Persis cabang Cianjur dan ustadz Qomarudin, ketiganya didaulat menjadi penceramah. Sesepuh Persis, A. Hasan menjadi penasehat acara (Al-Mawaidz, No. 9-10, 2 Februari-5 Maret 1935: 139).

Materi ceramah yang

dikemukakan kepada jamaah adalah tentang sumber hukum dalam agama Islam. Dalam isi ceramahnya, Ustad Qomarudin menyampaikan bahwa sumber hukum Islam ada dua, yaitu Al-Qur'an dan Hadis saja. Dia mengkritik perilaku kalangan tradisional yang sering menjadikan Ijma' (kesepakatan para ulama) dan Qiyas (perumpamaan) ulama sebagai dasar hukum agama Islam di samping Al-Qur'an dan Hadits. Sebagaimana pandangan umum kaum modernis, Ustad Qomarudin mengemukakan bahwa tradisi-tradisi keagamaan yang berkembang di kalangan umat Islam yang dihasilkan dari ijma' sedangkan tidak ada nas dalam Al-Qur'an dan Hadis adalah sebuah bentuk penambahan syariat. Amaliah yang dilakukan daripadanya adalah bid'ah, sehingga kalau pun dilaksanakan maka amalan tradisi itu tidak akan diterima oleh Allah, pemilik syariat ${ }^{4}$.

Masalah kedua yang disoroti oleh Persis dalam acara itu adalah tentang kebiasaan kaum tradisional yang kerap menggunakan kitab-kitab klasik/kitab kuning karangan para ulama sebagai salah satu dasar hukum agama. Menurut $\mathrm{H}$. Romli yang menjadi penceramah ketiga, bahwa kebiasaan tersebut malah mempersulit pengambilan hukum agama. Kitab-kitab fiqih yang dipergunakan di dunia pesantren seperti Fathoel Moein, Fathoel Wahab dan sebagainya, hanyalah pendapat-pendapat yang dikarang oleh manusia biasa (Al-Mawaidz, No. 9-10, 2 Februari-5 Maret 1935: 139-140).

Dari sekian banyak jamaah, hadir dalam acara tabligh akbar itu empat orang pengurus NU cabang Tasikmalaya. Setelah para mubalig selesai berceramah, kemudian empat orang itu maju ke depan, mengajukan pertanyaan. Mereka adalah KH. Dahlan dari Cicarulang, KH. Fadlil dari Cikotok, H. Ahmad Syadili dari Sukahaji, dan Soetisna Sendjaja. Salah satu pertanyaan yang diajukan oleh pihak NU adalah tentang bagaimana memahami nash Al-Qur'an ajaran Islam secara komprehensif tanpa merujuk pada ijma dan hasil ijtihad ulama yang banyak dituangkan dalam kitab-kitab klasik. Kemudian pihak NU mengajukan pertanyaan tentang beberapa hal yang berkaitan dengan praktik ibadah.

Pertanyaan-pertanyaan

yang diajukan oleh pihak NU dijawab oleh para penceramah Persis, namun karena masing-

4 Sejak tahun-tahun sebelumnya, masalah bid'ah telah menjadi masalah serius yang menjadi fokus utama perhatian Persis. Mereka membahas masalah ini dalam majalah-majalah yang mereka publikasikan. Lihat Pembela Islam No. 7, bulan April 1930. 
masing punya argumen akhirnya sesi tanya jawab tidak menemukan titik temu atas apa yang ditanyakan dan apa yang dijelaskan. Oleh karena perdebatan tidak kunjung selesai, dua pihak tetap pada pendirian masing-masing saling lempar argumen tanpa menghasilkan kesimpulan yang jelas, maka Soetisna Sendjaja dalam kapasitasnya sebagai ketua NU cabang Tasikmalaya memberikan arahan penutup. Sebagai berikut.

"Djisimkoering ti kapoengkoerna gadoeh angen-angen hajang kempel djeng doeloer ti Persis pikeun ngamoesjawarakeun masalah-masalah anoe pakia-kia. Namoeng paneda teh hajang kiai pada kiai bae. Oerang, andjeun (bari noendjoek ka poeblik) djeung koering bisa miloe nimbang, henteu ngan oekoer njengseurikeun. Koe sabab eta manga oerang moesjawarah. Bisa bae sapagodos noehoen. Hnteu bae, oerang njieun perdjangdjian oelah rek silih gorengkeun" (Al-Mawaidz, No. 9-10, 2 Februari-5 Maret 1935: 140).

Pada bulan November 1935 NU dengan Persis kembali terlibat perdebatan. Kali ini yang menjadi tuan rumah adalah NU cabang Bandung. Pada tanggal 15 November 1935 NU cabang Bandung mengumumkan penyelenggaraan tablig akbar yang akan dilaksanakan pada tanggal 18 November 1935. Tablig akbar itu akan diisi oleh beberapa penceramah, dan yang bertindak sebagai penceramah utama adalah KH. Wahab Hasbullah. Tema yang akan diangkat oleh para mubalig adalah

5 Saya dari dulu punya angan-angan untuk berkumpul dengan sodara-sodara dari Persis untuk bermusyawarah permasalahan yang bertolak belakang. Namun inginnya, cukup antara kyai dengan kyai saja. Kita, anda dan saya bisa menimbang, tidak cuma sebatas menertawakan. Oleh karena itu mari kita bermusyawarah. Kalau bisa saling setuju, terima kasih. Kalau tidak, kita bikin perjanjian agar supaya di antara kita tidak saling menjelek-jelekan.” "kewajiban taqlid", sebagai bentuk penguatan kepada nahdliyin akan pentingnya mengikuti madzab empat imam. Informasi itu sampai kepada pengurus Persis di Bandung, maka para tokoh Persis yang berpaham anti taqlid, bermaksud menanggapi tema yang akan diangkat pada acara tersebut. Mereka mengirim surat yang ditujukan kepada NU cabang Bandung, sebagai berikut.

"Telah tersiar chabar, bahwa pada malam Senen 17 November 1935, toean Hadji Abdoel Wahhab ketoea Nahdlatoel Oelama, akan berchoetbah di mesdjid Bandoeng, salah satoenja di tentang masalah wadjib taqlied kepada 'Oelama. Mas'alah itoe sebenarnja amat penting dan kami pertjaja, sebagai mana biasa, tidak akan diberi kesempatan boeat bertoekar fikiran atas djalan tanja menanja di mesdjid itoe. Lantaran itoe kami harap toean Hadji Abdoel Wahhab suka memboeang tempoh mengoeraikan mas'alah itoe di mesjid Persatoean Islam, kapan sadja ia soeka, tetapi diharap sangat kalau bisa di dalam tiga atau empat hari ini. Kalau tidak soeka datang di tempat kami boeat menerangkan masalah taqlied itoe, maka kami harap Nahdlatoel Oelama Bandoeng memberi kesempatan boeat kami berchoetbah di tempat toeantoean di tentang tidak boleh taqlied dengan beralasan Qoer'an dan Hadits dan 'Oelama Ahli Soennah waldjama'ah. Sekali lagi kami Oelangkan, bahwa lantaran masalah ini sangat penting, harap ketoea-ketoea Nahdlatul Ulama jang soeka membela kebenaran, akan datang ke tempat kami atau soeka terima kedatangan kami di tempat toean-toean boat bertoekar pikiran, Wassalam "Goeroegoeroe Persatoean Islam" (Al-Lisaan, No. 1, 27 Desember 1935: 1-2).

Pada awalnya pengurus NU cabang Bandung menolak permintaan Persis, dengan alasan pertemuan yang 
dihasilkan tidak akan menghasilkan keputusan apa-apa. Perdebatan yang terjadi antara NU dengan Persis tidak akan mengubah pendirian masing-masing pihak. Atas penolakan yang disampaikan oleh Said Hasan Wiratama (voorzitter NU cabang Bandung), Persis membuat selebaran-selebaran tentang keharaman taqlid yang ditujukan kepada KH. Wahab Hasbullah. Selebaran ini kemudian disebarkan kepada masyarakat dengan harapan terjadi keramaian di tengah masyarakat yang ujungnya pihak NU bersedia untuk berdebat. Strategi Persis berhasil, NU cabang Bandung bersedia melakukan perdebatan terbuka dengan Persis perihal masalah taqlid. Berikut adalah surat tanggapan yang disampaikan pengurus NU cabang Bandung.:

Bersama ini soerat, dari kita kaoem N.O. soedah menimbang dan memoetoeskan bahwa permintaan Toean-toean itu dikaboelkan dan waktoenja nanti malam Selasa tanggal 18 dan ke 19. Toean-toean dipersilakan datang di tempat Cloebhoeis Nahdlatoel Oelama di Kopoweg. Pembitjaraan akan dimoelai djam 8 ba'da isja'. Jang diperkenankan datang dari Toean2 hanja boeat 6 orang sadja, dari 6 orang itoe jang diperkenankan boeat menerangkan masalah terseboet hanja boeat 1 orang sahaja. Wassalam daripada kita Bestuur N.O. Tjabang Bandoeng ( $A l$ Lisaan, No. 1, 27 Desember 1935: 4).

Pada pelaksanaannya, orang-orang Persis yang datang ke tempat acara adalah berjumlah 40 orang. Mereka dipimpin oleh guru utama Persis, yaitu A. Hassan. Sementara di pihak tuan rumah, dipimpin langsung oleh KH. Wahab Hasbullah. Selain itu hadir juga beberapa kiai yang menjadi tokoh NU di wilayah Priangan, seperti KH. Ruhiyat dari Tasikmalaya, KH. RA. Dimyati dari Babakan Ciparay Sukamiskin dan KH. Syamsuddin dari Lembang. KH. Abdul Wahhab tampil lebih dulu memaparkan pendapatnya tentang "wajibnya taqlid". Lalu kemudian Tuan A. Hassan tampil ke atas mimbar memaparkan pendapatnya tentang "haramnya taqlid". Kedua orang ini saling memberikan hujjah atas pemahaman masing-masing.

Dalam pandangan A. Hassan dari Persis, bahwa Allah mengharamkan umat Islam untuk taqlid kepada siapapun, walau setinggi apapun keilmuan yang diikutinya, kecuali hanya boleh mengikuti perintah Allah dan Rasul-Nya. Orang-orang yang bisa berijtihad, wajib ittiba', yaitu mengikuti siapa saja dengan mengetahui dalil yang dikemukakan orang yang diikuti. Sementara itu, para kiai NU tetap pada pendiriannya, bahwa "kewajiban taqlid" tetap berlaku bagi sebagian besar umat Islam. Dalam pendapat KH. Abdul Wahab orang yang tidak bisa berijtihad, wajib taqlid kepada salah salah satu dari imam mazhab yang empat. Taqlid itu terkadang dengan disertai tahu dalil dan terkadang bisa dengan tanpa tahu dalil. Orang-orang awam yang tidak tahu dalil, cuma perlu ikut perkataan para gurunya. Orang Islam tidak perlu memaksakan ittiba', yaitu mengikuti sesudah tahu alasan dari orang yang diikuti. Adapun bagi orang yang mampu ijtihad, boleh melakukan ijtihad kalau mempunyai kapasitas ilmu agama yang mumpuni.

Sampai pertemuan itu selesai, kedua kelompok tetap bertahan pada argumen masing-masing. Sebelum ditutup, KH. Ruhiyat, KH. RA. Dimyati dan KH. Syamsuddin menyampaikan nasehat kepada semua yang hadir. Inti dari nasehat ketiga kiai tersebut adalah supaya umat Islam tetap berpegang teguh pada ajaran Islam. Umat Islam diharapkan dapat menghargai perbedaan meskipun perdebatan kerap terjadi. Kebenaran dari siapa pun hendaknya dapat diterima dengan lapang dada tanpa melihat "kaum tua" atau "kaum muda". Setelah itu, kemudian Said Hasan Wiratama, ketua NU cabang Bandung mengucapkan terima kasih atas kehadiran A. Hasan beserta seluruh rombongan dari Persis, seraya 
menutup acara (Al-Lisaan, No. 1, 27 Desember 1935: 5).

Masalah yang sama kembali diperdebatkan oleh NU dan Persis pada 31 Mei 1936 di Gebang. Pihak NU Ciledug dimotori oleh KH. Masduqi, H. Abdul Khair dan Awad Basit, sementara pihak modernis dari Persis dan Al-Irsyad diketuai oleh A. Hasan dan didampingi oleh pengurus Al-Irsyad cabang Cirebon, yaitu H. Moehsin dan H. Aliman. Perdebatan berlangsung dari jam 09.00 pagi sampai sore hari. Selain para tokoh yang akan berdebat, hadir pula para pendukungnya. Tidak ketinggalan hadir pada kesempatan itu petugas keamanan, pejabat agama serta pejabat administrasi setempat (Anam, 2010: 48).

Seperti pada perdebatanperdebatan sebelumnya, A. Hassan tetap berpendirian bahwa taqlid hukumnya adalah haram. Menurutnya, Allah telah mewajibkan umatnya berpegang teguh hanya pada tali agama Allah, dan melarang berpegang kepada yang lainnya. Ini artinya, umat Islam dilarang bertaqlid. Keberadaan Al-Qur'an dan Hadis sudah menjadi cukup bukti bahwa mengikuti kepada selain keduanya adalah dilarang. Kalau memang taqlid itu diwajibkan, tentulah ada anjurannya. Kemudian, A. Hassan meminta kepada KH. Masduqi untuk menunjukkan anjuran tersebut dari ayat Al-Qur'an, kalau memang ada. Sebaliknya, KH. Masduqi meminta A. Hassan untuk menunjukkan ayat AlQur'an yang secara eksplisi melarang taqlid. Bagi KH. Masduqi, ayat tentang "berpegang teguh pada tali agama Allah", bukan merupakan larangan untuk manut kepada ulama. Ijtihad yang dilakukan para ulama juga merupakan bagian dari usaha untuk berpegang teguh pada tali agama Allah, karena ijtihad yang mereka lakukan pasti bersandar pada Al-Qur'an dan Hadis $^{6}$. Kedua belah pihak lagi-lagi tidak

${ }^{6}$ Jawaban serupa pernah disampaikan oleh $\mathrm{KH}$. Ahmad Sanusi, tokoh AII, atas pendapat KH. Muhammad Zakaria dari pihak MASC yang mengharamkan taqlid kepada pendapat para mendapatkan titik temu, karena satu pihak tidak dapat menunjukkan ayat Al-Qur'an yang secara eksplisit mengharamkan taqlid, di pihak lain tidak dapat menunjukkan ayat yang mewajibkannya. Kedua pihak hanya sepakat, bahwa ulama adalah pewaris ilmu-ilmu yang diturunkan oleh Nabi (Al-Lisaan, No. 9, 20 Agustus 1936: 37-38).

Satu lagi perdebatan Antara NU dengan Persis terjadi pada tahun 1937. Kali ini yang menjadi bahan perdebatan adalah masalah hukum memegang AlQur'an dengan tanpa wudu dan masalah batal atau tidaknya wudu seseorang apabila bersentuhan dengan lawan jenis. Perdebatan ini terjadi pada tanggal 23 dan 24 Januari 1937 di rumah salah seorang anggota NU cabang Batavia Centrum yang terletak di Pasar Baru Jakarta. Di antara yang maju ke arena debat adalah A. Hassan, Ali Harharah, H. Tamim, dan Abdoellah Ahmad dari Persis. Sementara dari pihak NU adalah KH. Wahab Hasbullah yang didampingi oleh Usman Perak. Adapun yang bertindak sebagai moderator, pada tanggal 23 Januari adalah

ulama. menurut KH. Ahmad Sanusi, jika tidak boleh bertaqlid kepada para ulama, lalu dari siapa para guru MASC mengetahui ilmu AlQur'an dan Hadits? Ilmu-ilmu dan pengetahuan agama yang sampai kepada para ulama MASC itu datang dari siapa, dari ulama ataukah wahyu? Jelas ilmu pengetahuan agama itu datang melalui para ulama terdahulu. Ini artinya harus diakui bahwa pendapat para ulama dapat juga dijadikan dalil atau hujjah dalam praktik keagamaan. KH. Ahmad Sanusi juga meminta pihak MASC dan kaum modernis pada umumnya untuk menunjukkan kitab-kitab mana saja dari para ulama yang nyata bertentangan Al-Qur'an dan Hadits. Kemudian, ayat Al-Qur'an dan Hadits mana saja yang dapat menyebutkan bahwa kitabkitab karangan para ulama itu sesat, sehingga membuat orang yang ittiba' kepada mereka menjadi kufur dan musyrik. Pertanyaan ini tidak mendapat jawaban dari KH. Muhammad Zakaria dan tokoh MASC lainnya. Lihat Iskandar (2001: 219-222). 
H. Abdul Majid, dan pada tanggal 24 Januari ditetapkan H. Mursalin. Keduanya adalah tokoh agama setempat (Al-Lisaan, No. 15, 27 Februari 1937: 33).

Menurut A. Hassan, memegang Al-Qur'an tanpa berwudu adalah hukumnya boleh karena tidak ada dalil yang melarangnyaa. Bahkan Imam Syafi'i, yang mazhabnya dianut oleh kalangan NU, membolehkan anak-anak untuk menyentuh Al-Qur'an tanpa berwudu terlebih dahulu. Seharusnya, kalau memang menyentuh AlQur'an tanpa berwudu itu haram, maka baik anak-anak maupun orang dewasa tetap tidak diperbolehkan. Sebagaimana haramnya babi, baik orang dewasa maupun anak-anak tetap tidak boleh memakan daging babi. Sementara menurut $\mathrm{KH}$. Wahab Hasbullah menyentuh Al-Qur'an wajib berwudu terlebih dahulu. Ini demi menjaga kesucian Al-Quran, dan etika pembaca kepada kitab sucinya. Al-Qur'an boleh disentuh tanpa wudu jika dalam mushaf Al-Qur'an itu terdapat terjemah atau tafsirnya.

Dalam masalah yang kedua, A. Hassan menyentuh lawan jenis tidak dapat membatalkan wudu, kecuali menyentuh dalam pengertian hubungan badan. Karena hukum telah menetapkan bahwa menyentuh ayah-ibu dan saudara-saudara sedarah, tidak membatalkan wudu. Sedangkan Usman Perak berpendapat bahwa bersentuhan dengan lawan jenis dapat membatalkan wudu, kecuali orangorang yang telah disebutkan oleh A. Hassan tadi, karena mereka termasuk kategori mahrom yang tidak boleh dinikahi (Al-Lisaan, No. 15, 27 Februari 1937: 34$35)$.

Dari sekian kali perdebatan yang telah dilakukan NU dengan Persis di Jawa Barat $^{7}$, nampaknya memang kedua belah

\footnotetext{
${ }^{7}$ Ada sebuah hal yang menarik dari perhelatan perdebatan antara NU dengan Persis di Jawa Barat. Setiap kali perdebatan digelar, maka dua tokoh utama NU dan Persis akan hadir di sana; mereka adalah KH. Wahab Hasbullah dan A. Hassan. Kedua tokoh ini sebenarnya telah lama saling kenal dari sebelum organisasi NU dan
}

pihak tidak pernah menemukan titik temu untuk bersepakat dalam menentukan hukum. Mereka bersikukuh dengan argumen masing-masing. Akan tetapi yang patut disayangkan adalah bahwa argumenargumen yang pernah mengemuka dalam setiap perdebatan tersebut, tidak pernah terpublikasikan secara detail. Terdapat sebuah kecenderungan di mana hasil-hasil perdebatan antara kedua belah pihak itu, seringkali diberitakan secara berlebihan yang kadang tidak proporsional dalam mengungkapkan bagaimana sesungguhnya proses debat terjadi.

Umumnya, media massa yang terbit dalam kurun waktu itu lebih banyak dikuasai oleh pihak reformis, sehingga sedikit banyak lebih menguntungkan pihak reformis. Situasi seperti itu ditambah oleh sikap kalangan tradisional sendiri yang kurang perhatian dalam mencatat dan mempublikasikan setiap jalannya perdebatan secara massif. Dimungkinkan ini karena ke-"tradisional"-annya itu, sehingga kebanyakan masyarakat awam yang tidak meny aksikan secara langsung, tidak tahu bagaimana perdebatan itu

Persis berdiri. Informasi ini bisa kita dapatkan dari catatan G.F. Pijper yang merupakan sahabat dari A. Hassan. Pijper menuturkan sebagai berikut:"Pada tahun 1921 dia pindah ke Surabaya untuk berdagang. Secara kebetulan di kota ini dia bertemu dengan Kiai Haji Abdul Wahab dan kepada kiai ini, A. Hassan banyak bercerita tentang agama. Kiai inilah yang pertama-tama mengajak A. Hassan untuk menelaah dasar-dasar hukum agama Islam, yaitu ilmu fikih, umpamanya tentang niat pada waktu hendak salat. Kiai ini menekankan bahwa mengucapkan niat itu tidak ada dasar hukumnya di dalam Qur'an maupun Hadits. Hassan kurang mempercayainya; keesokan harinya dia membeli buku-buku tentang soal ini dan juga membaca kumpulan hadits Bukhari dan beberapa bahan bacaan lainnya dan akhirnya dia mendapat jawaban yang membenarkan apa yang dipersoalkan oleh Kiai Haji Abdul Wahab. Inilah yang menjadi pangkal tolak usahanya untuk memperdalam pengetahuannya di bidang agama" (Pijper, 1985: 127). 
persisnya. Sementara kaum reformis begitu rajin mencatat perdebatan-perdebatan itu secara rinci dan detail, bahkan publikasinya tidak hanya dalam majalah atau surat kabar, melainkan juga dalam buku-buku yang diterbitkan.

Sebagai contoh, dalam Verslag Debat Talqin yang dimuat dalam majalah Al-Lisaan, penulis menemukan argumen dari pihak NU yang menganjurkan taqlid ada sebanyak 21 dalil. Satu persatu dari 21 dalil tersebut dituliskan bantahannya oleh Persis. Sedangkan bantahan dari pihak NU atas 73 dalil Persis yang mengharamkan taqlid sama sekali tidak dimuat (Al-Lisaan, No. 1, 27 Desember 1935: 7-20). Begitu pun perdebatan yang dilakukan pada tahun 1932 di Cirebon antara para kiai NU dengan para kiai dari Persis dan MASC. Majalah Tjahaja Islam milik MASC menuliskan argumen yang dikemukakan oleh KH. Muhammad Anwar Sanusi secara panjang lebar dan detail. Sedangkan argumen dari KH. Abdul Khair hanya beberapa saja yang mendapat tempat. Majalah hanya memberitakan bahwa KH. Abdul Khair membaca kitab kuning, adapun argumen apa yang diambil dari kitab itu dan bagaimana penjelasannya, tidak dipublikasikan. Seperti dituliskan berikut ini:

Tidinja toeloej T. Kiai Aboel Chaer matja kitab basa Malajoe djeung basa Arab, anoe samaroek andjeunna mah eta katrangan teh bisa ngoeatkeun kana tangtoengan andjeunna, padahal eta katrangan teh basa Malajoe djeung basa Arab anoe harita koe andjeunna dibatja, sama sakali euweuh anoe bisa djadi hoedjah dina madzhab "Ahli Soennah Waldjama'ah", lantaran eta noe dibatja koe T. Kiai Aboel Chaer teh ngan woengkoel karangan djeung pamandangan Oelama-Oelama anoe sadaek-daek bae ${ }^{8}$ (Tjahaja Islam, No. 28, bulan Juni 1932: 8).

8 Dari sana kemudian KH. Abdul Khair membaca kitab berbahasa Melayu dan bahasa
Menurut Iskandar (2001: 250) hal seperti ini sering dijadikan semacam referensi oleh para penulis yang meneliti dinamika pergerakan organisasi Islam untuk melihat kejumudan para kiai dan ulama tradisional.

\section{Konsensus Umat Islam}

Seperti yang dikemukakan oleh Cosser, bahwa motivasi untuk mengakhiri konflik bisa saja karena lelah atau bosan, atau karena ingin mencurahkan tenaganya kepada hal lain yang dianggap lebih penting. Dari sini, konflik secara tidak langsung dapat membantu mengeratkan ikatan kelompok yang terstruktur secara longgar. Masyarakat yang mengalami disintegrasi, atau berkonflik dengan masyarakat lain, dapat memperbaiki kepaduan integrasi. Sebuah kohesi dapat diciptakan dari konflik antar kelompok melalui sebuah aliansi di antar kelompok itu (Ritzer dan Goodman, 2010: 159).

Fenomena pertentangan yang terjadi di kalangan umat Islam sejak tahun 1920-an pada akhirnya menemukan titik kulminasi. Memasuki tahun 1930-an, muncul beberapa peristiwa yang memberikan kesadaran kepada umat Islam bahwa integrasi adalah modal utama perjuangan melawan kekuatan-kekuatan luar yang sebenarnya sudah sejak lama menyudutkan eksistensi kaum muslim. Serangan terhadap umat Islam datang dari pemerintah Kolonial Hindia Belanda dan dari kaum Nasionalis Sekuler. Umat Islam juga harus berhadapan dengan kaum adat yang berusaha mempertahankan hukum adat dan menginginkan pengikisan hukum

Arab, yang menurutnya keterangan itu dapat menguatkan pendapatnya. Padahal keterangan yang berbahasa Melayu dan bahasa Arab yang ia baca itu sama sekali tidak ada yang bisa jadi hujjah dalam madzhab Ahlu Sunnah Wal Jama'ah, karena apa yang dibaca oleh KH. Abdul Khair itu cuma karangan dan pandangan ulama-ulama yang semaunya saja". 
agama di seluruh Nusantara (Benda, 1985: 116).

Atas beberapa peristiwa yang terjadi, memasuki tahun 1935, para tokoh dari beberapa organisasi Islam mulai berfikir pentingnya Ukhuwah Islamiyah. Baik tokoh-tokoh Islam tradisional maupun golongan modernis, menyadari bahwa integrasi kaum muslim merupakan masalah yang lebih penting daripada sekedar meributkan masalah furu' dan perbedaan tradisi keagamaan. Tokoh Muhammadiyah KH. Mas Mansur yang merasa prihatin atas konflik yang berlarutlarut dalam sebuah pidatonya berkata:

"Pada beberapa tahun yang sudah, kita gemar berbantah-bantahan, bermusuhmusuhan di antara kita umat Islam. Malahan perbantahan dan permusuhan itu di antara ulama dengan ulama. Sedang yang dibuat perbantahan itu perkara hukum kecil-kecil saja. Adapun timbulnya permusuhan itu, karena kebanyakan kita berpegang kuat pada hukum yang dihukumkan oleh manusia. Sehingga suatu perkara di utara menyatakan sunnah, di selatan menyatakan makruh, di barat menyatakan wajib, di timur menyatakan haram, begitulah seterusnya sehingga umat Islam yang awam dibuat bal-balan oleh ulama kita. Sana benci kepada sini. Sini benci kepada sana. Kita sekarang bukan hidup pada 25 tahun lalu (sudah), kita sudah bosan, kita sudah payah bermusuh-musuhan. Sedih kita rasakan kalau perbuatan itu timbul daripada ulama, padahal ulama itu semestinya lebih halus budinya, berhati-hati lakunya. Karena ulama itu sudah ditentukan menurut firman Allah: 'Ulama itu lebih takut pada Allah.' Karena ulama tentunya lebih paham dan lebih mengerti kepada dosa dan bahayanya bermusuh-musuhan" (Maarif, 1996: 18).

Keprihatinan serupa ditunjukkan oleh Rois Akbar Nahdlatul Ulama. Pada
Kongres NU kesebelas di Banjarmasin tahun 1936, KH. Hasyim Asy'ari di hadapan segenap muktamirin memberikan nasehatnya agar supaya umat Islam mau bersatu dan meninggalkan perilaku ta'ashub (fanatisme golongan). Dalam pidatonya, KH. Hasyim As'ari berseru kepada segenap umat Islam:

"Telah sampai kepadaku suatu berita, bahwa di antara kamu sekalian sampai saat ini masih mengorbankan api fitnah dan perselisihan. Wahai ulama-ulama yang telah ta'ashshub kepada setengah madzhab atau setengah qaul! Tinggalkanlah ta'ashshubmu dalam soal-soal 'furu' itu!... Dan belalah agama Islam, berijtihadlah menolak orang-orang yang menghina Al-Qur'an dan sifat-sifat Tuhan. Alangkah baiknya jika tenagamu engkau sediakan buat itu. Wahai seluruh insan! Di hadapanmu sekarang berdirilah orang-orang kafir yang mengingkari Tuhan. Mereka telah memenuhi segala pelosok negeri ini. Siapakah diantara kamu yang bersedia tampil kemuka untuk berbahas dengan mereka dan berusaha menuntun mereka kepada jalan yang benar?... Adapun ta'ashshub kamu pada rantingranting agama, dan mendorongkan orang supaya memegang satu madzhab atau satu qaul, tidaklah disukai Allah Ta'ala! Dan tidaklah diridhai oleh Rasulullah SAW...Wahai ulamaulama! Kalau kamu lihat orang berbuat suatu amalan berdasarkan kepada qaul imam-imam yang boleh ditaqlidi, meskipun qaul itu hukumnya marjuh, maka jika kamu tidak setuju, janganlah kamu cerca mereka, namun beri petunjuklah dengan halus!... Janganlah kamu jadikan semuanya itu menjadi sebab buat bercerai-berai, berpecahbelah, bertengkar-tengkar, dan bermusuh-musuhan karena sesungguhnya yang demikian itu adalah melanggar hukum Tuhan dan dosa yang amat besar. Itulah yang menyebabkan runtuh-leburnya 
bangunan suatu bangsa, sehingga tertutuplah dihadapannya setiap pintu kepada kebajikan. Itulah sebabnya maka dilarang Allah, hamba-Nya yang beriman dari bertengkar-tengkaran... Belum jugakah tiba masanya kita insaf? Belum jugakah tiba masanya kita akan sadar dari kemabukan ini? Dan bangun dari kelalaian kita? Belum jugakah kita mengerti bahwa kemenangan kita semua bergantung kepada bantu-membantu dan persatuan yang padu diantara kita? Atau akan kita lanjutkan jugakah perpecahan ini, hina menghinakan, pecah memecah, munafik, pepat di luar pancung di dalam, rasa benci memenuhi hati, dan dengki merusak kawan, dan sesat pusaka lama!. Wahai kaum muslimin! Taqwalah kepada Allah, perbaikilah hubungan di antara kamu, bantu membantulah atas kebajikan dan taqwa, jangan berbantu-bantuan di atas dosa dan permusuhan..." (Noer, 1991: 261-262; Anam, 2010: 98-99; Hasib, 2015: 26).

Sebagai seorang ulama, KH. Hasyim Asy'ari menyadari bahwa betapapun besarnya kepentingan kelompoknya (dalam hal ini NU), apabila persoalannya sudah menyangkut agama Islam, maka segala kepentingan kelompok itu harus segera ditinggalkan. Kelompokkelompok yang ada bahkan seharusnya dapat menjadi wasilah terwujudnya integrasi seluruh umat Islam. Amanat KH. Hasyim Asy'ari tersebut kemudian disebarluaskan oleh cabang-cabang NU yang sudah terbentuk di seluruh Hindia Belanda. Para pengurus cabang NU dituntut untuk menyampaikannya dalam setiap acara yang dilaksanakan. Misalnya, amanat dari Rois Akbar HBNO itu disampaikan oleh KH. Abdul Halim pada bulan September 1936, dalam acara rapat pengurus ANO Cirebon. KH. Abdul Halim sebagai salah seorang sesepuh NU di Jawa Barat menyampaikan kepada para pemuda yang hadir agar segera meninggalkan sikap ta'ashub, saling mencela dan sikap berpecah belah sebagaimana instruksi dari KH. Hasyim Asy'ari pada Kongres NU bulan Juni di Banjarmasin (Al Mawa'idz No. 38: 23 September 1936: 571). Usaha NU untuk mewujudkan integrasi umat Islam kemudian diusahakan dalam Kongres NU kedua belas di Malang tanggal 20-24 Juni 1937. NU sengaja mengundang tokoh-tokoh Islam lintas organisasi dan mazhab untuk hadir pada kongres yang mereka selenggarakan. Dalam undangan tersebut dituliskan: “...kemarilah toen-toan jang mulia,
kemarilah, permoesjawaratan kita, marilah kita bermoesjawarah tentang apa2 jang mendjadi baiknja Igama dan oemat, baik poen oeroesan Igamanja, maoepoen doenianja, sebab doenia ini tempat mengoesahakan achirat dan kebadjikan tergantoeng poela atas beresnja perikedoeniaan... oleh karena oemat Islam itu bertingkat2 dan semuanja itoe bersaoedara. Mereka mempoenjai hak atas oelama dan oelama mempoenjai kewadjiban atas mereka" (Berita N.O. No. 16, 15 Juni 1937: 3).

Sikap simpatik lain datang dari organisasi Perserikatan Ulama dan AII. Usaha serupa di atas dilakukan oleh $\mathrm{KH}$. Abdul Halim yang mengundang wakilwakil dari organisasi lain dalam rapat-rapat Perserikatan Ulama. Antara lain mengundang Persis, Muhammadiyah, dan AII. Kemudian dalam Kongres Perserikatan Ulama kedua belas tahun 1936 di Cirebon, KH. Abdul Halim menyatakan bersedia membubarkan organisasinya, asalkan sudah ada persatuan umat Islam yang benar. pernyataan ini disambut baik oleh pihak AII, yang siap bekerja sama untuk tujuan itu (Iskandar, 2001: 265). Usaha-usaha yang digagas oleh para tokoh Islam itu pada akhirnya kian menyempitkan jurang perbedaan di antara organisasi-organisasi Islam, khususnya yang berhaluan Islam tradisional dengan kubu reformis. 
Dipelopori oleh NU dan Muhammadiyah, dibentuklah suatu federasi Islam yang baru dengan nama Madjlisul Islam A'la Indonesia (MIAI) atau Majelis Tinggi Islam Indonesia pada September 1937 di Surabaya (Benda, 1985: 119). Empat tokoh utama pelopor MIAI adalah KH. Mas Mansur dari Muhammadiyah, KH Muhammad Dahlan serta KH. Wahab Hasbullah dari NU dan Wondoamiseno dari Sarekat Islam (Ridwan, 2003: 118).

Pada bulan Desember 1937 dilangsungkan pertemuan pertama antar anggota MIAI. Pertemuan itu dihadiri perwakilan dari PSII, NU, Moehammadiyah, Al Irsyad, Partai Arab Indonesia dan beberapa organisasi Islam lainnya. Pertemuan ini memutuskan untuk menghidupkan kembali Kongres Al-Islam yang akan segera diselenggarakan tanggal 25 Februari sampai 1 Maret 1938 di Surabaya (Soerabaijasch Handelsblad, No. 298, Vol. 85, 27 Desember 1937). MIAI hanya bertahan selama enam tahun, pada tanggal 24 Oktober 1943 MIAI dibubarkan oleh pemerintah Jepang. Namun kehadiran MIAI telah menjadi konsensus bersama umat Islam di Hindia Belanda. Meskipun, karena MIAI bersifat sukarela dan bukan kesatuan aksi yang berdisiplin kuat, keberadaan aliansi yang baru ini juga tidak seutuhnya menghapuskan perbedaanperbedaan pendapat antara kaum reformis dan ortodoks (Benda, 1985: 119). Setidaknya, pergulatan pemikiran seputar furu dan khilafiyah dapat diredam oleh kepentingan bersama dalam MIAI. Intensitas perdebatan di antara tokoh-tokoh Islam lintas organisasi yang bahkan kerap dipertontonkan kepada publik, tidak lagi sesering sebelum MIAI didirikan. Di Jawa Barat, kebiasaan mengadakan Openbare Vergadering Debate oleh sebuah organisasi Islam tertentu, sejak tahun 1937 sudah jarang santer terdengar.

\section{PENUTUP}

Pergulatan pemikiran antara para kiai NU dengan kaum modernis dilatarbelakangi oleh perbedaan cara pandang mengenai sumber hukum dalam Islam. Para kiai NU dan ulama tradisional umumnya beranggapan bahwa kitab-kitab yang berisi ulasan-ulasan dan tafsirantafsiran isi Al-Qur'an dan Hadis yang telah ditulis oleh para ulama terdahulu, dapat menjadi dasar bagi pemahaman dan pengamalan ajaran-ajaran Islam. Mengikuti ulasan dan tafsiran para ulama terdahulu bukan tanpa alasan, mengingat para ulama terdahulu adalah orang-orang yang memiliki kapasitas untuk berijtihad. Selain itu, mengikuti ijma' ulama sama artinya dengan menghindarkan diri dari memahami Al-Qur'an secara tekstual saja. Kalau semua umat Islam diharuskan "hanya menggunakan Al-Qur'an dan Hadis" sebagai sumber hukum, dari mana masyarakat awam dapat memahami kandungan dan maksud di balik ayat AlQur'an yang multi tafsir. Karena faktanya, tidak semua orang diberi kemampuan untuk berijtihad.

Sebaliknya, dalam pemahaman kaum Islam modernis, untuk memahami dan mengamalkan ajaran-ajaran Islam yang murni, kaum muslim harus mendasarkan pengetahuan dan amalannya hanya kepada Al-Qur'an dan Hadis, tanpa embel-embel ijma' ulama. Hukum yang diambil dari hasil pemikiran para ulama memungkinkan akan munculnya suatu bentuk penambahan pada syariat yang telah ditetapkan. Bagi mereka, sikap taqlid kepada salah satu imam mazhab adalah sebuah bentuk kejumudan. Umat Islam yang tidak mampu berijtihad harus berittiba', yaitu mengikuti pendapat ulama dengan mengetahui secara pasti argumen dari ulama yang diikutinya. Semboyan kaum modernis adalah "kembali kepada Al-Qur'an dan Hadis". Segala perilaku keberagamaan yang tidak tercantum dalam nash Al-Qur'an dan Hadis, maka hukumnya tertolak.

Adanya perbedaan dalam proses pengambilan sumber hukum tersebut, sejurus kemudian memunculkan pendekatan yang berbeda dalam menyikapi budaya keagamaan yang berkembang di 
tengah-tengah masyarakat. Kalangan tradisionalis, terutama para kiai NU, dalam menyikapi tradisi yang berkembang di masyarakat biasanya berpegang pada kaidah "Al muhaafadlotu 'alal kodiimish shoolih wal akhdza biljadiidil ashlah" yang artinya memelihara niai-niai terdahulu yang sudah baik dan mengambil nilai-nilai baru yang lebih baik. Pendekatan adaptasi dapat dilakukan dalam menyikapi tradisi/budaya yang secara prinsip tidak bertentangan dengan syariat (tidak haram). Bahkan, budaya dapat dijadikan sebagai sarana dakwah Islam itu sendiri. Oleh karena banyaknya sumber rujukan -di samping Al-Qur'an dan Hadis- yang diambil dari pendapat para ulama, telah menumbuhkembangkan sikap fleksibel di kalangan para kiai NU. Sebaliknya, di kalangan kaum modernis, pada umumnya beranggapan bahwa tradisi yang dianggap bukan dari Islam, apalagi tidak terdapat dalam nash Al-Qur'an secara tersurat, adalah wajib untuk ditinggalkan oleh umat Islam. Islam sudah sempurna, tidak boleh ditambah dengan hal-hal baru dari tradisi di luar Islam. Karena setiap hal baru dari tradisi di luar ajaran Islam adalah termasuk kategori "bid'ah". Sedangkan yang bid'ah tidak ada yang bernilai baik, semua bid'ah adalah sesat dan tercela.

Pergulatan pemikiran yang demikian itu menjadi sumber utama munculnya disintegrasi di tengah-tengah umat Islam dalam kurun waktu 1920-1930an. Dalam tahun-tahun tersebut perdebatan-perdebatan tentang apa yang menjadi perbedaan di atas kerap mengemuka ke hadapan publik. Sampai akhirnya, karena didorong oleh kepentingan bersama dalam rangka melawan kekuatan dari luar Islam, memasuki tahun 1937 pihak-pihak yang berkonflik tersebut berbesar hati untuk menyingkirkan perbedaan pendapat yang berkepanjangan itu, dan menggantinya dengan saling memahami makna perbedaan tersebut. Mereka menemukan konsensus dalam sebuah organisasi pemersatu berbentuk Majelis Islam A'la Indonesia (MIAI). Meskipun pada suatu saat nanti pertentangan dan letupan-letupan perbedaan akan kembali muncul, tetapi sepanjang saat itu pula para tokoh Islam berpeluang untuk memiliki konsensus bersama lagi, dan selalu ada alasan untuk mengikat kembali tali ukhuwah Islamiyah. Umat Islam pun pada akhirnya akan menyadari bahwa perbedaan adalah sebuah keniscayaan, tapi persatuan adalah kewajiban yang harus diusahakan.

\section{DAFTAR SUMBER}

\section{Arsip dan Dokumen Tercetak}

HBNO. (1926). Statuten Perkoempoelan Nahdlatoel Oelama Fatsal 1926. Soerabaja.

\section{Buku}

Anam, Choirul. (2010).

Pertumbuhan dan Perkembangan NU. Surabaya: PT. Duta Aksara Mulia.

Garraghan, Gilbert J.S.J. (1957)

a guide to historical method. New York: Fordham University Press.

Gottschalk, Louis. (2006). Mengerti Sejarah. Jakarta: UI Press.

Haidar, M. Ali. (1994). Nahdlatul Ulama dan Islam di Indonesia, Pendekatan Fiqih dalam Politik. Jakarta: Gramedia.

Herlina, Nina. (2015). Metode Sejarah. Yayasan Masyarakat Sejarawan Indonesia Cabang Jawa Barat.

Iskandar, Mohammad. (2001).

Para Pengemban Amanah, Pergulatan Pemikiran Kiai dan Ulama di Jawa Barat 1900-1950. Yogyakarta: Mata Bangsa.

Ismaun. (2005).

Pengantar Sejarah Sebagai Ilmu dan Wahana Pendidikan. Bandung: Historia Utama Press.

Ma'rif, Ahmad Syafii. (1996). Islam dan Politik Teori Belah Bambu Masa Demokrasi Terpimpin (1959-1965). Jakarta: Gema Insani. 
Nasution, Harun. (1974).

Islam ditinjau dari Berbagai Aspeknya, jilid 2. Jakarta: Bulan Bintang.

Noer, Deliar. (1991).

Gerakan Modern Islam di Indonesia. Jakarta: LP3S.

Nugroho, M. Yusuf A. (2012). Fiqih Al-Ikhtilaf NU-Muhammadiyah. Wonosobo: TP.

Pijper, G.F. (1985).

Beberapa Studi Tentang Sejarah Islam di Indonesia 1900-1950. Penerjemah Tudjimah dan Yessy Agusdin. Jakarta: UI Press.

Renier, G. J. (1997).

Metode dan Manfaat Ilmu Sejarah. Yogyakarta. Pustaka Pelajar.

Ridwan, Kafrawi dkk. (2003).

Ensiklopedi Islam JIlid 3. Jakarta: PT. Ichtiar Baru van Hoeve.

Ritzer, George dan Goodman, Douglas J. (2010).

Teori Sosiologi Modern. Terjemah oleh Alimandan. Jakarta: Kencana Prenada Media Grup.

Sjamsuddin, Helius. (2007).

Metodologi Sejarah. Yogyakata: Ombak.

Zuhri, Saifuddin. (1979).

Sejarah Kebangkitan Islam dan Perkembangannya di Indonesia. Bandung: $\quad$ PT Ma'arif.

\section{Majalah}

"Extra Nomor Debat Taqlied" dalam AlLisaan. No 1. 1 Syawal 1354/27 Desember 1935. Bandoeng.

"Bagian debat" dalam Tjahja Islam. Jilid II. No. 3. Bulan Agustus 1930.

"Bid'ah dholalah" dalam Pembela Islam. No. 7. Bulan April 1930.

“Oendangan dan Garis Besarnja N.O.” dalam Berita N.O. Tanggal 15 Juni 1937/6 Rabiul Awal. No. 16. Tahun ke-VI. Soerabaja.

"Openbare N.O. bagian A.N.O" dalam $A l$ Mawa'idz. No. 38 Tanggal 23
September 1936: $571 \quad$ tahun ke 4.

Tasikmalaja.

“Openbare Vergadering N.O." dalam AlMawa'idz, No. 51. Tanggal 18 Desember 1934. Tasikmalaja.

"Perang Debat, Verslag Ringkas Debat di Betawi" dalam Al-Lisaan, No. 15. Tanggal 9 Dzulhijjah 1355 H/27 Februari 1937. Bandoeng.

"Persatoean Islam di Tasikmalaja" dalam AlMawaidz. No. 9-10. Tanggal 26 Februari-5 Maret 1935. Tahun ke3. Tasikmalaja.

“Tabligh Oemoem N.O." dalam Al-Mawaidz. No. 9-10. Tahun ke-3. Tanggal 26 Februari-5 Maret 1935. Tasikmalaja.

"Verslag Debat Taqlied Di Madrasah Al-Irsjad Gebang" dalam Al-Lisaan No. 9. Tanggal 7 Dzumadil Akhir/ 20 Agustus 1936. Bandoeng.

"Verslag Ringkes Openbare Debat Vergadering Kiai Nahdlatoel Oelama Tjirebon Contra Kiai Modern" dalam Tjahaja Islam. No. 28. Bulan Juni 1932.

Majalah Pembela Islam No. 7, bulan April 1930.

\section{Surat Kabar}

"Al-Islam Congres" dalam De Indische Courant, No. 40 Vol. 2. Tanggal 1 November 1922. Soerabaja.

"Het Al Islam Hindia Congres" dalam De Indische Courant. No 104, Vol. 5. Tanggal 18 Januari 1926. Soerabaja.

"Het Al Islam Congres" dalam Soerabaijasch Handelsblad. No. 298, Vol. 85. Tanggal 27 Desember 1937. Soerabaja.

Hasib. "Indonesia Ideal Menurut KH. Hasyim Asy'ar" dalam Republika Tanggal 20 Agustus 2015. 